\title{
Inadvertent subretinal injection of botulinum toxin
}

\section{Inyección inadvertida de toxina botulínica subretiniana}

Jorge A. Sánchez-Ramos ${ }^{1 *}$, Ezequiel Díaz-Benítez ${ }^{1}$ Ángeles Y. Hernández-Vázquez¹, Carla R. Pérez-Montaño, Sergio Rojas-Juárez ${ }^{1}$, Juan A. Ramírez-Estudillo ${ }^{1}$ and Fernando Zavaleta-Herrera²

${ }^{1}$ Retina and Vitreous Department; ${ }^{2}$ Strabismus Department. Fundación Hospital Nuestra Señora de la Luz, Mexico City, Mexico

\begin{abstract}
Case Report: This is a 19-year-old male with bilateral external rectus muscle palsy secundary to trauma. During treatment, an inadvertent intraocular injection of botulinum toxin was present, causing a retinal tear and localized retinal detachment. Both lesions were delimited with laser observing a spontaneous resolution of the detachment without presenting visual impairment during the follow-up. Discussion: Although intraocular botulinum toxin does not generate retinal toxicity, inadvertent intraocular injection should be closely monitored to avoid complications secondary to perforation.
\end{abstract}

Key words: Botulinum toxin. Inadvertent intraocular injection. Retinal tear.

\section{Resumen}

Caso clínico: Se trata de un paciente masculino de 19 años con paresia bilateral del músculo recto externo secundario a un traumatismo craneoencefálico. Durante su tratamiento se produjo una inyección intraocular inadvertida de toxina botulínica, ocasionando un desgarro retiniano y desprendimiento de retina localizado. Ambas lesiones fueron delimitadas con láser, observándose una resolución espontánea del desprendimiento sin presentar deterioro visual durante el seguimiento. Discusión: A pesar de que la toxina botulínica intraocular no genera toxicidad a nivel retiniano, la inyección intraocular inadvertida debe ser vigilada de manera estrecha para evitar complicaciones secundarias a la perforación.

Palabras clave: Toxina botulínica. Inyección intraocular inadvertida. Desgarro retiniano.

Correspondence:

*Jorge Arturo Sánchez-Ramos

E-mail: jorgesr84@ hotmail.com
Available online: 08-05-2019 Rev MexOftalmol(Eng).2019;93(3):129-132

www.rmo.com.mx 2604-1731/@ 2019 Sociedad Mexicana de Oftalmología. Published by Permanyer México SA de CV. This is an Open Access article under the CC BY-NC-ND license (http://creativecommons.org/licenses/by-nc-nd/4.0/).

Date of reception: 13-03-2017

Date of acceptance: 07-05-2017

DOI: 10.24875/RMOE.M19000067 


\section{Introduction}

Botulinum toxin is a neurotoxin produced by Clostridium botulinum, which acts selectively on the cholinergic nerve terminals, blocking acetylcholine release, leading to a decrease in stimulus conduction, and therefore in postsynaptic muscle activity ${ }^{1}$.

The use of botulinum toxin for strabismus treatment is widely known since 1973, when Scott et al. carried out the first experimental studies to support human use $\mathrm{e}^{2,3}$

Botulinum toxin in paralytic strabismus acts preventing contracture of the muscle that antagonizes the paretic one during approximately 6 to 8 weeks, improving binocular vision in primary gaze and allowing functional recovery of the affected muscle $e^{1,4}$.

Since it is an invasive procedure, the injection of the extraocular muscles can have some complications such as scleral perforation, vitreous hemorrhage and retinal detachment ${ }^{4,5}$.

\section{Clinical case}

This is the case of a 19-year-old male with sixth bilateral cranial nerve palsy secondary to severe head trauma four months before his visit. He attended consultation due to horizontal diplopia with a 50 prism diopters (PD) endodeviation. Best-corrected visual acuity was 20/25 in the right eye and 20/40 in the left eye. Due to the clinical characteristics, we decided to treat with $15 \mathrm{IU}$ of botulinum toxin in both medial rectus muscles. Two weeks later, he showed improvement of the horizontal deviation, with a consecutive 6 PD exotropia, evidencing a good response to treatment. However, 3 months later, the endodeviation returned to $30 \mathrm{PD}$, so $10 \mathrm{IU}$ of toxin were applied again to both medial rectus muscles.

Immediately after the application of the toxin in the medial rectus of the left eye, the patient reported myodesopsia and a relative scotoma in the temporal sector; we performed dilated-pupil fundus examination observing a retinal tear in the nasal sector with a subretinal bubble of at least 10 disc diameters (Fig. 1), with an intraocular pressure of $12 \mathrm{mmHg}$ and with preserved visual acuity. The patient was immediately evaluated by the retina department, deciding to apply laser around the tear and the bubble.

Forty-eight hours after the injection, complete re-absorption of the subretinal bubble was observed, with no other changes in the retina (Fig. 2). Intraocular pressure remained normal and visual acuity was unchanged.

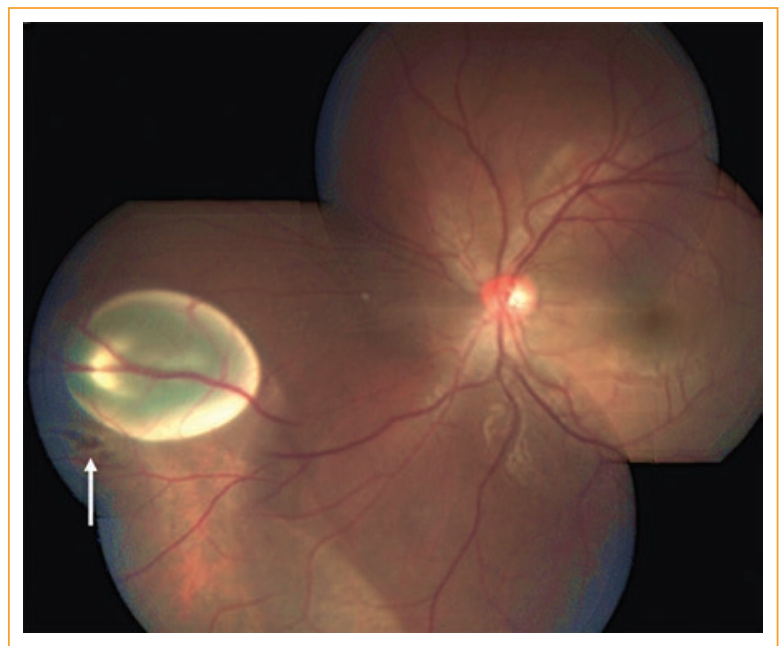

Figure 1. Left eye fundus showing the subretinal toxin bubble in the nasal sector, with an inferior retinal tear (arrow).

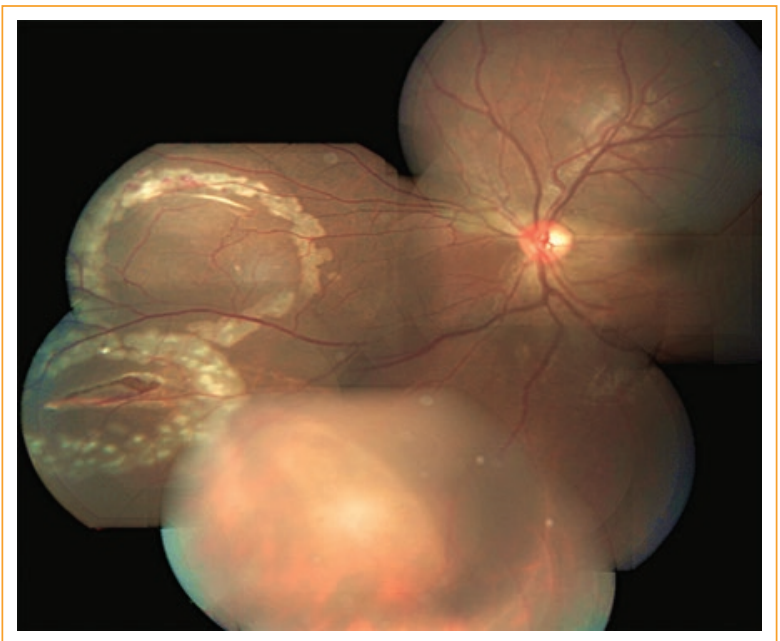

Figure 2. Left eye fundus with laser spots around the tear and the bubble, which reabsorbed spontaneously 48 hours after the injection.

Two months after the event, an electroretinogram showed a normal rod-cone response (Fig. 3). At three months, follow-up of the retinal lesions was completed, observing an applied retina with the expected laser scars and a visual acuity of $20 / 40$.

\section{Discussion}

The use of botulinum toxin in strabismus was widely used and approved by the Food and Drug Administration (FDA) after the research done by Scott who applied 


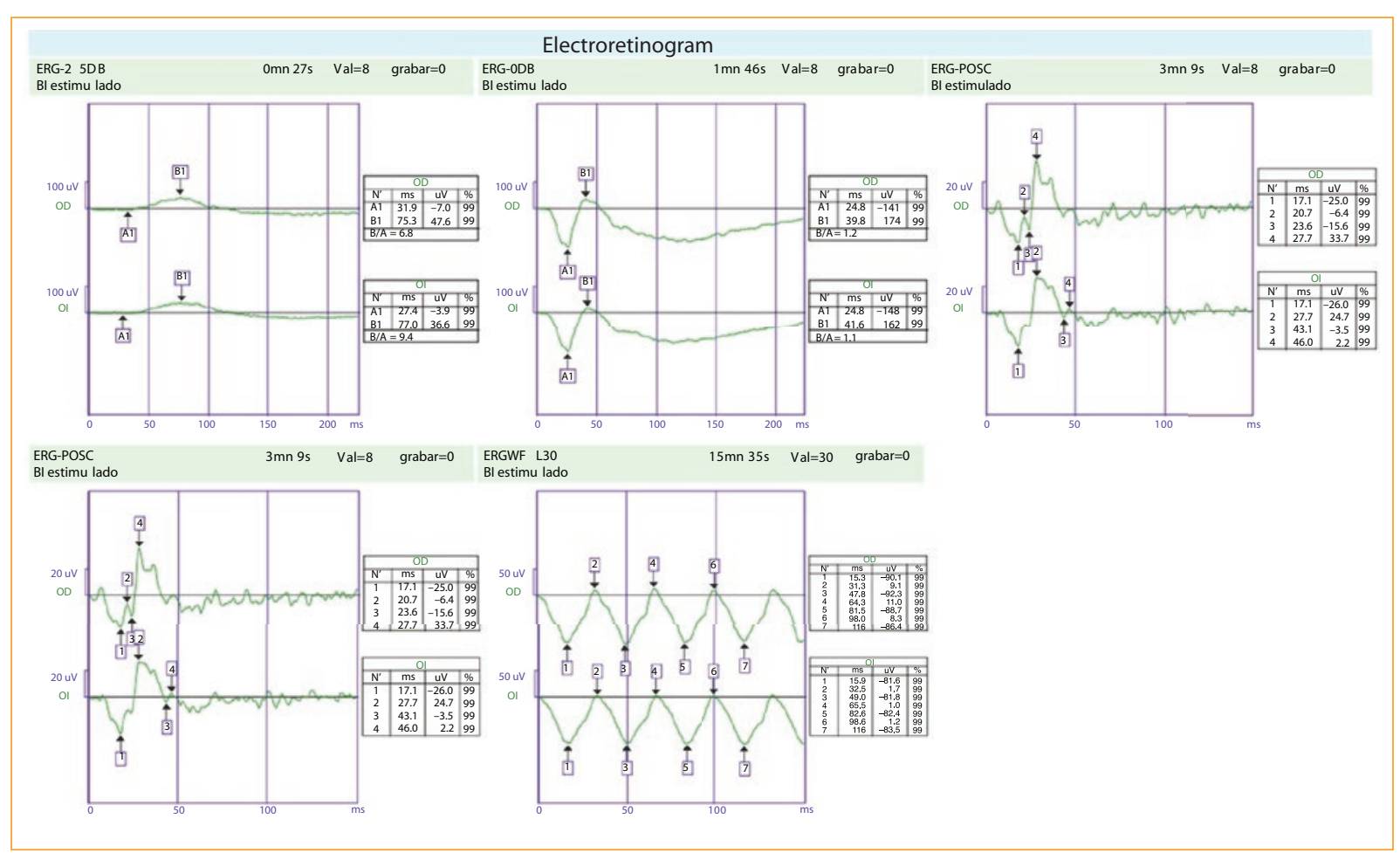

Figure 3. Electroretinogram two months after the procedure observing an adequate rod-cone response.

8,300 toxin injections, from which only 9 cases of scleral perforation and vitreous hemorrhage were observed ${ }^{6}$.

Ocular perforation is one of the least frequent complications with this therapy. There are few reports similar to ours, in which intraocular toxin toxicity has not been observed ${ }^{4,5,7}$.

Regarding the most relevant acute complications reported in the literature, sudden increase of intraocular pressure accompanied by a significant decrease in visual acuity stands out. Liu et al. ${ }^{4}$ chose to perform an anterior chamber paracentesis, unlike Leung et al. ${ }^{5}$ who prescribed treatment with topical and systemic hypotensives, achieving an adequate intraocular pressure control in both cases.

In our case, the visual disturbances referred by the patient are justified by the clinical findings in the retina, without a decrease in visual acuity. In addition, the patient did not show significant changes in intraocular pressure, probably because of the low amount of toxin that penetrated the eyeball.

Due to the retinal tear, we considered necessary to apply laser to prevent the development of a rhegmatogenous retinal detachment; also, laser was applied around the bubble to prevent the toxin from migrating to the macula since it was unclear for us the toxin behavior at the subretinal level, although we later observed a rapid resorption 48 hours after the injection. A latent concern is the intraocular toxic effect that botulinum toxin may have. Several studies carried out in rabbits injected with intraocular botulinum toxin at different doses did not detect retinal function deterioration during the follow-up by ophthalmoscopy, electroretinogram and visual evoked potentials ${ }^{8-10}$.

The clinical evolution of our patient was similar to the one observed in the cases reported in the literature, like the lack of visual acuity loss at the end of the follow-up and absence of intraocular toxicity demonstrated by electroretinogram. However, close follow-up in these patients is warranted to avoid the development of significant complications such as optic nerve damage due to a sustained increase in intraocular pressure or retinal detachment secondary to the predisposing retinal lesion caused.

\section{Conclusions}

Intraocular botulinum toxin can be well tolerated because it does not induce toxic effects in the retina; however, it is necessary to closely monitor these patients to avoid complications secondary to perforation such as ocular hypertension and rhegmatogenous retinal detachment. 


\section{Ethical disclosures}

Protection of human and animal subjects. The authors declare that no experiments were performed on humans or animals for this study.

Confidentiality of data. The authors declare that no patient data appear in this article.

Right to privacy and informed consent. The authors declare that no patient data appear in this article.

\section{Funding}

The authors received no specific funding for this work.

\section{Conflicts of interest}

The authors declare no conflicts of interest.

\section{References}

1. Crouch ER. Use of botulinum toxin in strabismus. Curr Opin Ophthalmol. 2006; $17: 435-40$

2. Scott AB, Rosenbaum A, Collins CC. Pharmacologic weakening of extraocular muscles. Invest Ophthalmol. 1973:12:924-7.

3. Scott AB. Botulinum toxin injection into extraocular muscles as an alternative to strabismus surgery. J Pediatr Ophthalmol Strabismus. 1980;17:21-5.

4. Liu M, Lee HC, Hertle RW, et al. Retinal detachment from inadvertent intraocular injection of botulinum toxin A. Am J Ophthalmol. 2004;137:201-2.

5. Leung AK, Keyhani K, Ashenhurst M. Retinal tear and raised intraocular pressure following unintentional intraocular botulinum toxin type A injection. Can J Ophthalmol. 2007;42:746-7.

6. Scott AB. Botulinum toxin treatment of strabismus. Focal points 1989 : Clinical modules for ophthalmologists, Vol VII, Module 12. San Francisco: American Academy of Ophthalmology; 1989. p.1-11.

7. Pehere N, Jalali $S$, Mathai $A$, et al. Inadvertent intraocular injection of botulinum toxin A. J Pediatr Ophthalmol Strabismus. 2011;48:e1-3.

8. Wienkers $\mathrm{K}$, Helveston EM, Ellis FD, et al. Botulinum toxin injection into rabbit vitreous. Ophthalmic Surg. 1984;15:310-4.

9. Hoffman RO, Archer SM, Zirkelbach SL, et al. The effect of intravitreal botulinum toxin on rabbit visual evoked potential. Ophthalmic Surg. 1987;18:118-9.

10. Kutluk S, Akar S, Topcu M, et al. Effect of botulinum toxin injections into the rabbit eye. Strabismus. 1999;7:221-6. 